\title{
Distal Ventriculoperitoneal Catheter Migration Revealed by Radionuclide Shuntogram
}

\section{Migração de Cateter Ventriculoperitoneal Distal Revelada por Cisternoventriculografia de Radionuclídeos}

\author{
(D) Andreia Baptista Marques ${ }^{1, *}$, (D) Fernando Abreu ${ }^{1}$, (D) Melissa Cruz ${ }^{1}$, (D) Sophia Pintão ${ }^{1}$ \\ 1-Serviço de Medicina Nuclear / Centro Hospitalar de Lisboa Ocidental, Lisboa, Portugal
}

DOI: https://doi.org/10.46531/sinapse/IN/210017/2021

\section{Case}

A 37-year-old woman with a history of idiopathic intracranial hypertension and ventriculoperitoneal (VP) shunt placement 12 years before, presented with right upper abdominal pain and occasional pulsatile headache. As a shunt malfunction was suspected, a radionuclide shuntogram was performed following the injection of $\mathrm{ImCi}$ sodium pertechnetate $\left.{ }^{99 \mathrm{~m}} \mathrm{TcO}_{4}\right)$ into the reservoir.

The early images demonstrated activity in the reservoir and distal tube (Fig. 1), and an absence of free diffusion of the tracer in the peritoneal cavity with a kink at the distal limb could be seen on the 2-hour images (Fig. 2). ${ }^{1-2}$ The 4-hour single-photon emission computed tomography/

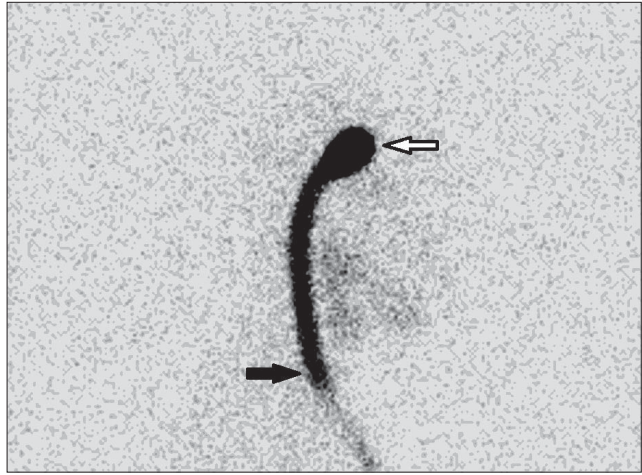

Figure 1. Right lateral planar scintigraphy of the head performed 10 minutes after injection of 1 $\mathrm{mCi}$ of ${ }^{99} \mathrm{mcO}_{4}$, showed activity in the reservoir (white arrow) and in the distal tube (black arrow)

computed tomography (SPECT/CT) images of the abdomen confirmed distal shunt obstruction, due to migration of the distal catheter to the subphrenic space (Fig. 3). ${ }^{3}$

After surgical replacement of the VP shunt, the patient symptoms promptly improved.

\section{Discussion}

Idiopathic intracranial hypertension, also known as pseudotumor cerebri, is a condition due to elevated intracranial pressure (ICP) without a detectable cause. The most common

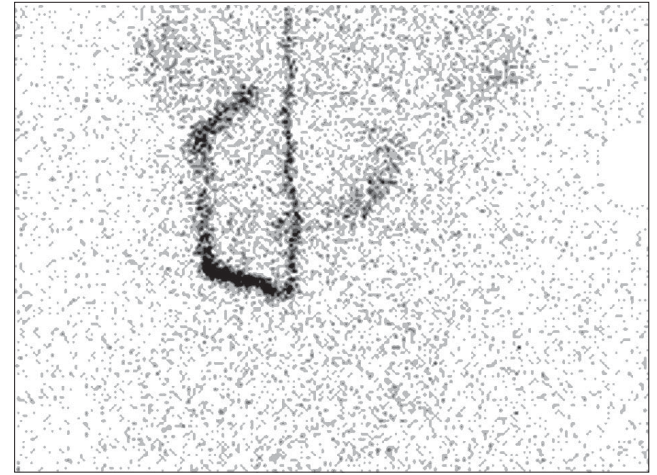

Figure 2. The 2-hour anterior planar scintigraphy of the abdomen demonstrated no activity diffusion in the peritoneal cavity with kink at the distal limb.

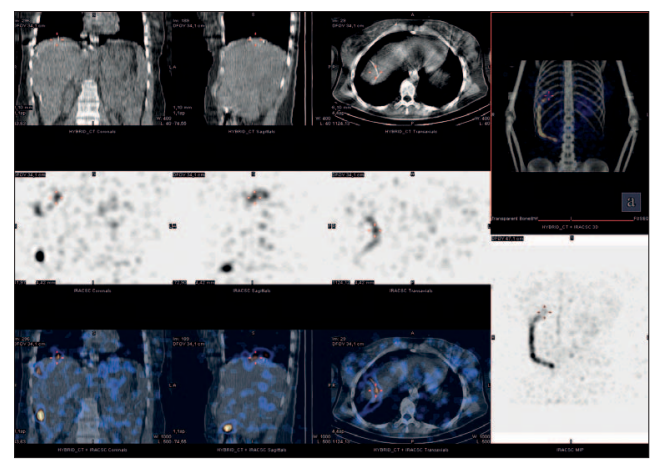

Figure 3. The 4-hour SPECT/CT images of the abdomen revealed that the distal tip of the shunt migrated into the subphrenic space.
Informações/Informations: Imagem em Neurologia publicado em Sinapse, Volume 21, Número 2, abril-junho 2021. Versão eletrónica em www.sinapse.pt Image in Neurology, published in Sinapse, Volume 21, Number 2, April-June 2021. Electronic version in www.sinapse.pt (C) Autor (es) (ou seu (s) empregador (es)) e Sinapse 2021. Reutilização permitida de acordo com CC BY-NC. Nenhuma reutilização comercial. (C) Author(s) (or their employer(s)) and Sinapse 2021 Re-use permitted under CC BYNC. No commercial re-use.

Keywords:

Prosthesis Failure;

Radionuclide Imaging;

Radiopharmaceuticals;

Ventriculoperitoneal Shunt.

Palavras-chave:

Compostos

Radiofarmacêuticos:

Derivação Ventriculoperitoneal; Falha de Prótese;

Imagem por Radionuclídeos.

\section{*Autor Correspondente / Corresponding Author: Andreia Marques \\ Av. Prof. Dr. Reinaldo dos \\ Santos, \\ 2790-134 Carnaxide \\ Oeiras, Portugal \\ anbmarques.md@gmail.com}

Recebido / Received: 2021-03-19 Aceite / Accepted: 2021-04-24 Publicado / Published: 2021-07-29 
symptoms include headaches, visual disturbances and nausea. These patients benefit from a cerebrospinal fluid shunting. ${ }^{4}$

The recurrence of symptoms related to increased ICP in a patient submitted to a previous therapeutic shunting may indicate shunt malfunctioning or obstruction. A radionuclide shuntogram with ${ }^{99} \mathrm{TcO}_{4}$ is useful in the assessment of shunt patency and obstruction site.

This unusual case highlights the utility of radionuclide shuntogram in the evaluation and management of patients presenting with shunt-related problems.

Responsabilidades Éticas

Conflitos de Interesse: Os autores declaram a inexistência de conflitos de interesse na realização do presente trabalho.

Fontes de Financiamento: Não existiram fontes externas de financiamento para a realização deste artigo.

Confidencialidade dos Dados: Os autores declaram ter seguido os protocolos da sua instituição acerca da publicação dos dados de doentes.

Consentimento: Consentimento do doente para publicação obtido.

Proveniência e Revisão por Pares: Não comissionado; revisão externa por pares.

\section{Ethical Disclosures}

Conflicts of Interest: The authors have no conflicts of interest to declare.

Financing Support: This work has not received any contribution, grant or scholarship.

Confidentiality of Data: The authors declare that they have followed the protocols of their work center on the publication of data from patients.

Patient Consent: Consent for publication was obtained.

Provenance and Peer Review: Not commissioned; externally peer reviewed.

\section{References / Referências}

1. Chiewvit S, Nuntaaree S, Kanchaanapiboon P, Chiewvit P. Assessment lumboperitoneal or ventriculoperitoneal shunt patency by radionuclide technique: a review experience cases. World J Nucl Med. 2014;13:75-84. doi: 10.4103/1450-1147.139135

2. Mannelli L, Monti S, Shin D, Lomabardo I, Behnia F. Subcutaneously Obstructed Ventriculoperitoneal Shuntogram. Clin Nucl Med. 2015;40: 265-7. doi: 10.1097/ RLU.0000000000000625.

3. Sigg D, Rich R, Ashby S, Jabour B, Glass E. Radionuclide shuntogram demonstrating migration of distal ventriculoperitoneal shunt tubing out of the peritoneal cavity. Clin Nucl Med 2005;30:552-4. doi: 10.1097/01. rlu.0000170041.00657.fe.

4. Hoang K, Hooten K, Muh C. Shunt freedom and clinical resolution of idiopathic intracranial hypertension after bariatric surgery in the pediatric population: report of 3 cases. J Neurosurg Pediatr. 2017;20:511-6. doi: 10.3171/2017.6.PEDS17145. 